\title{
A World of Indigenous Languages
}




\section{LINGUISTIC DIVERSITY AND LANGUAGE RIGHTS}

Series Editor: Dr Tove Skutnabb-Kangas, Åbo Akademi University, Finland

Consulting Advisory Board:

François Grin, Université de Genève, Switzerland

Kathleen Heugh, University of South Australia, Adelaide

Miklós Kontra, Károli Gáspár University, Budapest

Robert Phillipson, Copenhagen Business School, Denmark

The series seeks to promote multilingualism as a resource, the maintenance of linguistic diversity, and development of and respect for linguistic human rights worldwide through the dissemination of theoretical and empirical research. The series encourages interdisciplinary approaches to language policy, drawing on sociolinguistics, education, sociology, economics, human rights law, political science, as well as anthropology, psychology and applied language studies.

All books in this series are externally peer-reviewed.

Full details of all the books in this series and of all our other publications can be found on http://www.multilingual-matters.com, or by writing to Multilingual Matters, St Nicholas House, 31-34 High Street, Bristol BS1 2AW, UK. 


\section{A World of Indigenous Languages}

Politics, Pedagogies and Prospects for Language Reclamation

Edited by

Teresa L. McCarty,

Sheilah E. Nicholas and

Gillian Wigglesworth 
DOI https://doi.org/10.21832/MCCART3064

Library of Congress Cataloging in Publication Data

A catalog record for this book is available from the Library of Congress.

Names: McCarty, T.L., editor. | Nicholas, Sheilah E. (Sheilah Ernestine), editor.| Wigglesworth, Gillian, editor

Title: A World of Indigenous Languages: Politics, Pedagogies and Prospects for Language Reclamation/Edited by Teresa L. McCarty, Sheilah E. Nicholas and Gillian Wigglesworth.

Description: Bristol; Blue Ridge Summit, PA: Multilingual Matters, 2019. Series: Linguistic Diversity and Language Rights: 17 | Includes bibliographical references and index.

Identifiers: LCCN 2018046180| ISBN 9781788923064 (hbk : alk. paper) | ISBN 9781788923057 (pbk : alk. paper) | ISBN 9781788923095 (kindle)

Subjects: LCSH: Language revival. | Linguistic minorities. | Language maintenance. | Language policy.

Classification: LCC P40.5.L357 W67 2019| DDC 306.44/9—dc23 LC record available at https://lccn.loc.gov/2018046180

\section{British Library Cataloguing in Publication Data}

A catalogue entry for this book is available from the British Library.

ISBN-13: 978-1-78892-306-4 (hbk)

ISBN-13: 978-1-78892-305-7 (pbk)

\section{Multilingual Matters}

UK: St Nicholas House, 31-34 High Street, Bristol BS1 2AW, UK.

USA: NBN, Blue Ridge Summit, PA, USA.

Website: www.multilingual-matters.com

Twitter: Multi_Ling_Mat

Facebook: https://www.facebook.com/multilingualmatters

Blog: www.channelviewpublications.wordpress.com

Copyright (C) 2019 Teresa L. McCarty, Sheilah E. Nicholas, Gillian Wigglesworth and the authors of individual chapters.

All rights reserved. No part of this work may be reproduced in any form or by any means without permission in writing from the publisher.

The policy of Multilingual Matters/Channel View Publications is to use papers that are natural, renewable and recyclable products, made from wood grown in sustainable forests. In the manufacturing process of our books, and to further support our policy, preference is given to printers that have FSC and PEFC Chain of Custody certification. The FSC and/or PEFC logos will appear on those books where full certification has been granted to the printer concerned.

Typeset by Nova Techset Private Limited, Bengaluru and Chennai, India. Printed and bound in the UK by Short Run Press Ltd. Printed and bound in the US by Thomson-Shore, Inc. 
To ancestors whose languages and voices have been carried to the present so that their descendants and those yet to come will receive the gifts - inheritance, birthright, history, and identity - that will guide them toward the future, and to all who work to sustain a world of Indigenous languages. Askwali. Ahéhee'. Thank you.

Front cover image: This photograph exemplifies how cultural understandings are passed on intergenerationally through the Indigenous language. Isaia Kealoha guides three kindergarten students as they learn how to work in the mâla 'uala, or sweet potato garden, as he did as a child from his elders. Special appreciation goes to Isaia Kealoha, Kalāmanamana Harman, Paeaokalani Lavin and Kekuahiwi Woods; photograph courtesy of Ke Kula 'O Nāwahīokalani`ōpu'u Iki Lab Public Charter School, Kea'au, HI, USA. 